\title{
Diana Tomić
}

dtomic@ffzg.hr

Filozofski fakultet Sveučilišta u Zagrebu

Hrvatska

Izvještaj o radu Odjela za fonetiku od lipnja 2016. do lipnja 2017.

U akademskoj godini 2016./2017. s radom je započelo predsjedništvo Odjela za fonetiku u sljedećem sastavu: dr. sc. Diana Tomić (Odsjek za fonetiku), dr. sc. Ivančica Banković Mandić (Croaticum - Centar za hrvatski kao drugi i strani jezik), dr. sc. Boška Munivrana (Poliklinika SUVAG) i Ivana Šušković, prof. (Microton d.o.o.). Predsjedništvo svojim sastavom odražava širinu djelatnosti fonetičara te će tijekom četverogodišnjeg mandata pripremom ciklusa nastojati ponuditi stručna predavanja za različite profile fonetičara. Tradicija redovitog održavanja stručnih predavanja nastavljena je i u prvoj godini mandata predsjedništva. Održana su dva ciklusa predavanja: Slušna pomagala - suvremeni pristup (koordinatorica ciklusa bila je Ivana Šušković, prof.) i Percepcija govora (koordinatorica ciklusa bila je dr. sc. Boška Munivrana). Predsjedništvo je održalo niz sastanaka na kojima se razgovaralo o statusu fonetičara na tržištu rada, o poteškoćama s kojima se fonetičari suočavaju i o mogućim rješenjima istih. Dogovoreno je da će članice predsjedništva nastaviti promicati struku unutar zajednice te pokušati povećati vidljivost i prepoznatljivost fonetičara kao zanimanja. Neupitno, uz članice predsjedništva, tome mogu doprinijeti i svi članovi Odjela za fonetiku Hrvatskoga filološkog društva, kao i ostalih strukovnih udruga.

\section{Predavanja i sastanci}

Tijekom akademske godine održano je osam stručnih predavanja raspoređenih u dva ciklusa:

1. Slušna pomagala - suvremeni pristup

- Davor Šušković, mag. ing. el. techn. inf.: Slušna pomagala danas - najnovija tehnologija (7. studenog 2016.) 
- Maja Lakuš, mag. educ. phon. rehab.: Jednostrano i/ili obostrano nošenje slušnih pomagala (28. studenog 2016.)

- dr. sc. Sanja Vlahović, dr. med.: Osobitosti dijagnostike i intervencije kod male djece oštećenog sluha (19. prosinca 2016.)

- prof. dr. sc. Robert Trotić, dr. med.: Kirurgija nagluhosti i gluhoće (30. siječnja 2017.)

- Stjepan Dubec, prof.: Dometi verbotonalne rehabilitacije (27. veljače 2017.)

2. Percepcija govora

- Sanja Lanc, mag. logopedije: Poremećaji slušnog procesiranja (27. ožujka 2017.)

- dr. sc. Maja Kelić: Fonološka obrada u djece s disleksijom (24. travnja 2017.)

- Mateja Konjevod, mag. educ. phon. rehab.: Utjecaj modifikacije govora na diskriminaciju frikativa u šestomjesečnih beba (22. svibnja 2017.).

\section{Godišnja skupština Odjela za fonetiku}

Godišnja skupština održana je 12. lipnja 2017. Podnesen je izvještaj o radu i aktivnostima Odjela u protekloj akademskoj godini i predstavljen je plan aktivnosti za iduću godinu, a članovi Odjela izvijestili su o sudjelovanjima na konferencijama i stručnim skupovima. Raspravljalo se o prostoru za održavanje redovitih sastanaka Odjela te je odlučeno da se u sljedećoj akademskoj godini predavanja Odjela za fonetiku opet održavaju u prostorijama Društva sveučilišnih nastavnika i drugih znanstvenika. Nove prostorije Društva nalaze se u Frankopanskoj 5 a/II. Osim mjesta održavanja predavanja, razgovaralo se i o posjećenosti samih predavanja te članstvu u Hrvatskome filološkom društvu. Podsjetili smo se na to da članarina u ovoj godini (temeljem odluke Predsjedništva HFD-a od 25. veljače 2016.) iznosi $100 \mathrm{kn}$ te da uključuje, uz predavanja, časopis Govor i popuste na cijenu kotizacije za skupove u organizaciji HFD-a te knjige u izdanju Društva. U protekloj akademskoj godini osnovana je Hrvatska strukovna udruga fonetičara, koja je uz Odjel za fonetiku Hrvatskoga filološkog društva i Udrugu fonetičara u zdravstvu treća strukovna fonetičarska udruga u Hrvatskoj. Također, Predsjedništvo je stupilo u kontakt s Hrvatskom udrugom audiologa i fonijatara koji, s obzirom na blisku profesionalnu suradnju, zainteresiranim fonetičarima omogućavaju članstvo. Naravno, treba spomenuti i Verbotonalnu udrugu u kojoj dio članova također čine fonetičari. Dakle, trenutno se za strukovna pitanja fonetičara zalažu tri udruge fonetičara te dvije udruge u kojima su fonetičari prihvaćeni članovi. Vjerujemo da će rad udruga ubrzati 
rješavanje pitanja fonetičara u praksi te da će se članovi triju fonetičarskih udruga sastati tijekom sljedeće akademske godine.

$\mathrm{Na}$ kraju službenog dijela skupštine članovima Odjela izvođenjem govora predstavili su se studenti fonetike s kolegija Govorništvo.

Govore su izveli:

- Mirna Rajaković - Engleski fonetičarima

- Katarina Beštak - Oni kradu, ali nama ne daju

- Dora Kolarić - Brzi i žestoki

- Karla Kočar - In vino veritas

- Fran Marković - Moj predsjednik.

\section{9. znanstveni skup Istraživanja govora}

Odjel za fonetiku Hrvatskoga filološkog društva i Odsjek za fonetiku Filozofskog fakulteta Sveučilišta u Zagrebu organizirali su Deveti znanstveni skup s međunarodnim sudjelovanjem Istraživanja govora. Skup je održan na Filozofskom fakultetu Sveučilišta u Zagrebu od 8. do 10. prosinca 2016. godine. Predsjednica Organizacijskog odbora bila je doc. dr. sc. Elenmari Pletikos Olof, a predsjednik Programskog odbora dr. sc. Nikolaj Lazić, izv. prof. Središnja tema skupa bila je prozodija govora. Plenarni predavači bili su prof. dr. sc. Carlos Gussenhoven (Sveučilište Radboud, Nijmegen, Nizozemska) s temom Evidence-based word prosodic structures i prof. dr. sc. Bettina Braun (Sveučilište Konstanz, Njemačka) s temom On the interplay between intonation and lexical processing in intonation languages. $\mathrm{Uz}$ središnju temu, Istraživanja govora donose nove spoznaje o retorici, argumentaciji i ostalim fonetskim temama pokazujući širinu fonetskih znanosti općenito, ali i specifičnosti Zagrebačke fonetike. Treba istaknuti i sesiju u spomen na profesora Branka Vuletića, o čijoj su fonetici i govornoj stilistici govorili doc. dr. sc. Jelena Vlašić Duić i dr. sc. Davor Nikolić, izložbu povodom 50 godina Odsjeka za fonetiku te velik broj sudionika iz inozemstva, što potvrđuje izniman trud Organizacijskog odbora.

\section{Izvještaji s konferencija, znanstvenih i stručnih skupova te ljetnih škola}

Članovi Odjela za fonetiku redovito aktivno sudjeluju na znanstvenim i stručnim skupovima u zemlji i inozemstvu. Na godišnjoj skupštini Odjela za fonetiku voditeljica je izvijestila članove o tim aktivnostima u ime sudionika. Professor emeritus 
Damir Horga održao je pozvano predavanje na Devetom stručnom savjetovanju za lektore hrvatskog jezika (Zagreb, 8. i 9. srpnja 2016.) pod naslovom Fluentnost govora, a sudjelovao je u radu dvaju skupova Fonetyka jazikow slovianskich (Torunj, Poljska, 16. i 17. rujna 2016.) i 31. međunarodnog znanstvenog skupa Hrvatskog društva za primijenjenu lingvistiku čija je tema bila Jezik i njegovi učinci. Kao i svake godine, članovi Odjela aktivno sudjeluju u radu HDPL-a, pa su uz profesora Horgu na skupu izlagale i Iva Bašić, Zdravka Biočina, Elenmari Pletikos Olof, Gordana VarošanecŠkarić i Ana Vidović Zorić. Velik broj naših članova sudjelovao je u radu novog skupa održanog u Mađarskoj (14. - 17. svibnja 2017.) Izazovi u analizi i obradi spontanoga govora (CAPSS2017) koji će svake dvije godine okupljati istraživače $s$ interesom za spontani govor. Pozvano predavanje održala je prof. dr. sc. Vesna Mildner pod naslovom Neurolinguistic aspects of speech processing. Uz nju, u radu skupa sudjelovali su članovi Odjela: Zdravka Biočina, Gabrijela Kišiček, Marko Liker i Gordana Varošanec-Škarić. Ivančica Banković-Mandić sudjelovala je u organizaciji i radu konferencije Hrvatski kao drugi i strani jezik (HIDIS) održane u Zagrebu (15. - 17. prosinca 2016.) u suautorstvu s Arnaldom Dobrić koja je također u protekloj godini sudjelovala na nekoliko skupova i ljetnih škola: Jornadas da Lingua Portuguesa (Zagreb, 29. rujna - 1. listopada 2016.), Making It New In English Studies (Maribor, Slovenija, 15. - 17. lipnja 2017.) i na 19. ljetnoj psiholingvističkoj školi (Balatonálmadi, Mađarska, 21. - 25. svibnja 2017.). Pozdravljamo znanstvene i stručne aktivnosti članova i veselimo se razmjeni znanja i iskustava.

\section{Časopis Govor}

Govor izlazi redovito. Godišnja pretplata na dva broja časopisa Govor iznosi 50 kn.

\section{Godišnja skupština Hrvatskoga filološkog društva}

Predsjedništvo Hrvatskoga filološkog društva održalo je sastanak 2. veljače 2017. te je sazvalo redovitu godišnju skupštinu Hrvatskoga filološkog društva 23. veljače 2017. $\mathrm{Na}$ skupštini su predsjednici odjela i urednici časopisa podnijeli izvještaje o radu. Predstavljen je i plan aktivnosti za 2017. godinu te su podneseni financijski izvještaji i planovi. Godišnja skupština tradicionalno je započela predavanjem i stručnim razgovorom na određenu temu koju je ove godine održala poslijedoktorandica dr. sc. Iva Nazalević Čučević pod naslovom: Sintaktička negacija u hrvatskome $i$ makedonskome jeziku. 